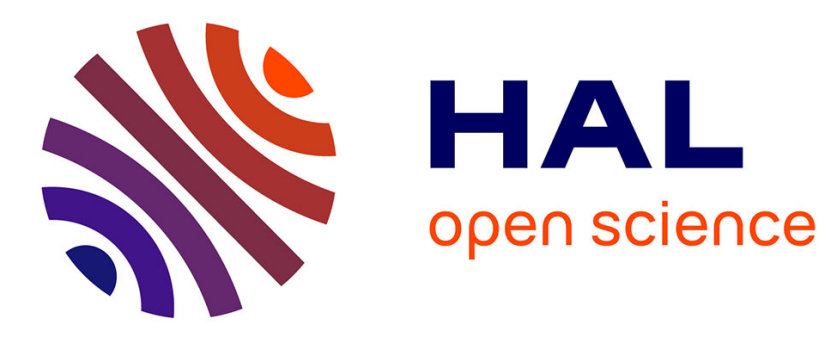

\title{
Callus Induction from Carob (Ceratonia siliqua L.) Seedlings and Leaves of Mature Tree
}

Brahim Bouzdoudi, R. Saïdi, Z. Nejjar El Ansari, M. Bouras, Alain Badoc, A. Lamarti

\section{- To cite this version:}

Brahim Bouzdoudi, R. Saïdi, Z. Nejjar El Ansari, M. Bouras, Alain Badoc, et al.. Callus Induction from Carob (Ceratonia siliqua L.) Seedlings and Leaves of Mature Tree. Annual Research \& Review in Biology, 2017, 19 (2), pp.1-13. 10.9734/arrb/2017/37037 . hal-03346218

\section{HAL Id: hal-03346218 \\ https://hal.science/hal-03346218}

Submitted on 16 Sep 2021

HAL is a multi-disciplinary open access archive for the deposit and dissemination of scientific research documents, whether they are published or not. The documents may come from teaching and research institutions in France or abroad, or from public or private research centers.
L'archive ouverte pluridisciplinaire HAL, est destinée au dépôt et à la diffusion de documents scientifiques de niveau recherche, publiés ou non, émanant des établissements d'enseignement et de recherche français ou étrangers, des laboratoires publics ou privés.

\section{(c)(1)}

Distributed under a Creative Commons Attribution| 4.0 International License 


\title{
Callus Induction from Carob (Ceratonia siliqua L.) Seedlings and Leaves of Mature Tree
}

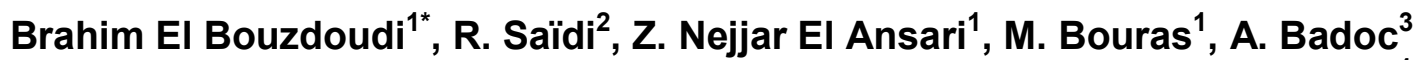 \\ and A. Lamarti ${ }^{1}$ \\ ${ }^{1}$ Laboratory of Plant Biotechnology, Biology Department, Faculty of Sciences, Abdelmalek Essaadi \\ University, Tetouan, Morocco. \\ ${ }^{2}$ Department of Matter and Life Sciences, High Normal School, Martil, Morocco. \\ ${ }^{3}$ Axe MIB (Molécules d'Intérêt Biologique), Unité de Recherche CEnologie EA 4577, USC 1366, INRA, \\ UFR des Sciences Pharmaceutiques, Université de Bordeaux, Institut des Sciences de la Vigne et du \\ Vin (ISVV), France.
}

\section{Authors' contributions}

This work was carried out in collaboration between all authors. All authors read and approved the final manuscript.

Article Information

DOI: $10.9734 / A R R B / 2017 / 37037$ Editor(s):

(1) George Perry, Dean and Professor of Biology, University of Texas at San Antonio, USA.

(1) Jayath P. Kirthisinghe, University of Peradeniya, Sri Lanka.

(2) Sheila Jazmín Reyes Zambrano, Instituto Tecnológico de Tuxtla-Gutiérrez, México. Complete Peer review History: http://www.sciencedomain.org/review-history/21733

Original Research Article

Received $27^{\text {th }}$ September 2017

Accepted $19^{\text {th }}$ October 2017

Published $3^{\text {rd }}$ November 2017

\section{ABSTRACT}

Callus induction was successfully carried out from several explants of carob (Ceratonia siliqua L.). Callogenesis from the apex was tested on three different media containing Woody Plant Medium (WPM), Murashige and Skoog (MS) or Schenk and Hildebrandt (SH) macronutrients supplemented with two different hormonal solutions: benzylaminopurine (BAP) at $4.44 \mu \mathrm{M}$ alone, or $2.22 \mu \mathrm{M}$ of BAP plus $5 \mu \mathrm{M}$ of 2-naphthalineacetic acid (NAA). Primary callus formation was obtained on a medium containing $88 \%$ WPM macronutrients. Callus formation from other parts of the plant was as follows:

- Cotyledon embryos extracted from immature seeds (85\% success rate on WPM medium, containing $4.44 \mu \mathrm{M} \mathrm{BAP}$ and $5 \mu \mathrm{M}$ NAA);

- Cotyledon leaves taken from 7-day-old seedlings, obtained from in vitro germination of seeds (62\% success rate on WPM medium, containing $4.44 \mu \mathrm{M}$ BAP and $5 \mu \mathrm{M}$ NAA); 
- Hypocotyls taken from 7-day-old seedlings (55\% success rate on WPM containing $2.22 \mu \mathrm{M}$ BAP and $5 \mu \mathrm{M} N A A)$;

- Differentiated leaves taken from mature tree ( $84 \%$ success rate on WPM medium, containing $4.44 \mu \mathrm{M}$ of BA and $2.26 \mu \mathrm{M}$ of NAA).

In general, production of primary calli and their growth after transplantation was better on WPM medium supplemented with $2.5 \mu \mathrm{M}$ NAA and $2.22 \mu \mathrm{M}$ BAP.

Keywords: Ceratonia siliqua L.; Callus induction; seedlings; mature tree.

\section{ABBREVIATIONS}

WPM: Woody Plant Medium; SH: Schenk and Hildebrandt; MS: Murashige and Skoog; BAP: 6Benzylaminopurine; NAA: 1-Naphthalene acetic acid; IAA: Indole-3-acetic acid; IBA: Indole-3-butyric acid; 2,4-D: 2,4-Dichlorophenoxyacetic acid; BNOA: $\beta$-Naphthoxyacetic acid; AIP: 2-Aminoindan-2phosphonic acid; FW: Fresh weight, DW: Dry weight.

\section{INTRODUCTION}

The carob tree (Ceratonia siliqua L.) is a longlived evergreen and thermophilous tree thriving in habitats with mild Mediterranean climates. It grows well in warm temperate and subtropical areas, and tolerates hot and humid coastal areas [1]. It is an important aromatic and medicinal plant that belongs to the family of Leguminosae and is currently considered among the most prominent fruit and forest trees existing in Morocco.

Due to its particular biological and agroecological features, such as resistance to salinity, adaptation to poor soils, and minimal cultural requirements, the carob tree was included in the national list of priority as forest resources for conservation in Morocco. This species is used in reforestation actions and its cultivation in modern orchards is being undertaken to value marginal lands and substitute for drought sensitive species [2].

The presence of wild trees growing adjacent to established orchards, as well as the great variation in sexuality of different carob varieties (male, female, hermaphrodite and polygamous inflorescences) causes great intraspecific variability and a large number of cultivars [3]. The high phenotypic variability within and between cultivars has important implications for selection, cultivation practices, and establishment of new plantations and productivity optimization of this crop [1].

Traditional carob propagation has been achieved by grafting saplings with female buds of chosen productive trees [1]. This traditional method of propagation has failed to meet the market demand for new, selected plant material. Thus, the use of micropropagation techniques seems to be appropriate, in order to fulfill the increased demand for propagating this tree [4]. Callus formation may be a useful tool to establish growth control and to study metabolism of forest tree species [5-7]. It can also lead to the differentiation of organs and even plants whose origin can be easily explored anatomically and experimentally in a sterile and simple nutritive culture [8-11].

Culture of different carob explants: from parts of young seedlings (cotyledonary leaves, hypocotyl, roots, meristems, lateral and axillary buds) [1221], meristems, lateral and axillary buds of adult female trees $[4,13,22-27]$, ova taken from female flowers [28], anthers of the male inflorescences of seed trees [29], immature seeds [30], mature cotyledons of seeds [31] and fruit tissue [32] is often accompanied by the formation of a callus whose importance varies according to the conditions studied.

The aim of the present study was to optimize an easy and reliable method for rapid propagation of induced callus from different parts of carob seedlings and leaves of mature trees.

\section{MATERIALS AND METHODS}

\subsection{Callogenesis from Apex of Young Seedlings Grown In vitro}

\subsubsection{Preparation of explants}

Mature carob pods were collected between August and September (2016) from a female tree, located at $30 \mathrm{~km}$ along the TetouanChefchaoun road in the Amtil region, Western 
Rif, Morocco. The harvested pods were shelled and the recovered seeds were disinfected with sulfuric acid $\left(\mathrm{H}_{2} \mathrm{SO}_{4}, 36 \mathrm{~N}\right)$ for $60 \mathrm{~min}$, followed by three rinses with sterile distilled water for $10 \mathrm{~min}$ each [33].

The disinfected seeds ( 30 seeds) were placed in $100 \mathrm{ml}$ flasks, containing $50 \mathrm{ml}$ of sterile distilled water and kept under stirring (10 rpm) for $48 \mathrm{~h}$ in a rotary shaker.

The seeds were then germinated in $200 \mathrm{ml}$ flasks containing $50 \mathrm{ml}$ of agar water $(0.7 \%, \mathrm{pH}=5.8)$ previously sterilized $\left(20 \mathrm{~min}\right.$ at $\left.120^{\circ} \mathrm{C}\right)$. Cultures were placed in an air-conditioned room at $25^{\circ} \mathrm{C}$, illuminated by fluorescent tubes (Philips, 40W) having an intensity of 800 lux. The photoperiod was 16 hours of light per day and the relative humidity was $85 \%$.

Apexes were collected from seven-day-old seedlings at the stage of two cotyledonary leaves, with a size of $4-5 \mathrm{~mm}$.

\subsubsection{Effect of macronutrients solutions}

$50 \mathrm{ml}$ of Three macronutrients solutions in 200 $\mathrm{ml}$ flasks $(50 \mathrm{~mm} \times 140 \mathrm{~mm}$ ) (Woody Plant Medium, WPM [34], Schenk and Hildebrandt, SH [35] and Murashige and Skoog, MS [36]), containing MS micronutrients and vitamins, 3\% of sucrose and $0.1 \mathrm{~g} / \mathrm{l}$ of myo-inositol, were used for callus induction from apex. 6Benzylaminopurine (BAP) was used at 2.22 and $4.44 \mu \mathrm{M}$, and 1-naphthalene acetic acid (NAA) at $5 \mu \mathrm{M}$. The $\mathrm{pH}$ was adjusted at 5.8 before autoclaving.

\subsubsection{Effect of growth regulators}

\subsubsection{Effect of auxins}

The study of callogenesis in the presence of different solutions showed that WPM medium is the most favorable to the development of calli. Thus, in order to determine the most suitable auxin for the induction of calli, the effect of four auxins was tested: indole 3-acetic acid (IAA), indole-3-butyric acid (IBA), NAA and 2,4dichlorophenoxyacetic acid (2,4-D). For each, four concentrations were tested: $0.5 ; 2.5 ; 5$ and $7.5 \mu \mathrm{M}$ in combination with $4.44 \mu \mathrm{M}$ BAP.

\subsubsection{Effect of different concentrations of BAP}

Experiments carried out in the presence of various auxins showed that NAA combined with $4.44 \mu \mathrm{M}$ of BAP is the most favorable for the development and maintenance of calli. Other combinations of NAA with various concentrations of BAP have been tested. The most favorable concentrations of this auxin were maintained, namely 5 and $7.5 \mu \mathrm{M}$, each combined with five concentrations of BAP: $0.44 ; 1.33 ; 2.22 ; 4.44$ and $6.66 \mu \mathrm{M}$.

\subsection{Callogenesis from Other Explants of Young Seedlings Grown In vitro}

Carob tree explants were very favorable for callus induction. Any organ could be used. Among these organs, cotyledonary leaves and hypocotyls from seven-day-old seedlings were tested. Embryonic cotyledons derived from immature fruit seeds harvested in June were also used, after disinfection according to the protocol of El Bouzdoudi et al. [37]. The base medium previously used was preserved, supplemented with $5 \mu \mathrm{M}$ NAA and 2.22 and $4.44 \mu \mathrm{M}$ BAP.

\subsection{Callogenesis from Leaves of Mature Female Tree}

\subsubsection{Preparation of explants}

Disinfection was carried out according to the protocol of Rolano et al. [38] with a $7 \%(\mathrm{w} / \mathrm{v})$ filtered solution of calcium hypochlorite $\left(\mathrm{Ca}(\mathrm{ClO})_{2}\right)$, containing few drops of Tween 80 for $20 \mathrm{~min}$, followed by rinsing with sterile distilled water for $5 \mathrm{~min}$, then with $0.1 \%(\mathrm{w} / \mathrm{v})$ mercuric chloride $\left(\mathrm{HgCl}_{2}\right)$ solution for $5 \mathrm{~min}$. $\mathrm{HgCl}_{2}$ is then removed by three successive rinses for 10,10 and $15 \mathrm{~min}$ in sterile distilled water.

The leaves used are those of the year, not very sclerified. They are placed in $200 \mathrm{ml}$ flasks containing $50 \mathrm{ml}$ of nutrient solution.

\subsubsection{Effect of macronutrients solutions}

In order to test the impact of WPM and MS macronutrients, two concentrations of BAP $(2.22$ and $4.44 \mu \mathrm{M}$ ) were each combined with $2.26 \mu \mathrm{M}$ ANA.

\subsubsection{Effect of different auxins}

As WPM solution was the most favorable for callogenesis, it was preserved to study the effect of six auxins (IAA, IBA, $\beta$-naphthoxyacetic acid (BNOA), 2-aminoindan-2-phosphonic acid (AIP), NAA and 2,4-D), each taken at a concentration of $2.26 \mu \mathrm{M}$ and combined with BAP (2.22 or 4.44 $\mu \mathrm{M})$. 


\subsection{Calli Growth after Transplanting}

\subsubsection{Effect of different auxins on the growth of calli}

The calli obtained from the culture of apex and cotyledonary leaves were transplanted onto the same base medium in the presence of NAA at 5 $\mu \mathrm{M}$ combined with the BAP at $2.22 \mu \mathrm{M}$, seven times during 21 days. After their stabilization, the calli were cultured in the presence of four auxins (IAA, IBA, NAA and 2,4-D) associated with the BAP $(2.22 \mu \mathrm{M})$. Two concentrations were chosen for each auxin (2.5 and $5 \mu \mathrm{M})$. After 21 days of culture and separation of the agar, the diameter of the callus and its fresh weight were measured. Each callus was packaged in aluminum foil and placed in an oven at $75^{\circ} \mathrm{C}$. After 15 days of dehydration, their dry weight was measured.

\subsubsection{Effect of NAA combined with BAP on calli growth}

As the combination of $2.5 \mu \mathrm{M}$ of NAA and $2.22 \mu \mathrm{M}$ of BAP was the best for callus growth, it was retained for the study of callus growth over time for 45 days. Every five days, the diameter and fresh weight of a sample of about twenty calli was determined, and the dry weight was estimated after 15 days of dehydration.

\subsection{Culture Conditions}

Cultures were placed in the culture room at an illumination of 4000 lux and a temperature of 23$25^{\circ} \mathrm{C}$ during the day and $20^{\circ} \mathrm{C}$ at night. The programmed photoperiod corresponded to 16 hours of light per day. Results were read after one month for callus initiation and 21 days for their multiplication.

\subsection{Statistical Analysis}

For all the studies conducted, thirty replicates per treatment were taken and and the experiments were repeated three times. Statistical analysis to find differences among treatments was done by one-way ANOVA using SPSS ver. 16 (SPSS Inc., Chicago, USA). The significance of difference among means was carried out using Duncan's multiple range tests at $P=.05$ and the results are expressed as mean \pm SE (standard deviation).

\section{RESULTS}

\subsection{Callogenesis from Apex of Young Seedlings Grown In vitro}

\subsubsection{Effect of macronutrients solutions}

Apex culture is accompanied by the formation of a callus that size varies according to the conditions studied. The percentage of callogenic explants as well as the diameter of the callus is greater on WPM medium supplemented with BAP at $4.44 \mu \mathrm{M}$. The MS medium is placed in the second position and, in the presence of 4.44 $\mu \mathrm{M}$ BAP, gives similar values without significant difference with those obtained on the WPM medium added with $2.22 \mu \mathrm{M}$ BAP. SH medium appears to be the most unfavorable to callogenesis. The state and the color of the calli are better on WPM and MS media (Table 1; Fig. $1 a, 1 b, 1 c)$.

\subsubsection{Effect of growth regulators}

\subsubsection{Effect of auxins}

Callogenesis from apex depends on the type of auxins and their concentrations. The NAA appears to be the most favorable for the development of calli. Indeed, the percentage of callogenic explants is maximum $(90.33 \%)$, as well as the diameter of callus $(14.1 \mathrm{~mm})$. The 2,4-D is in second place with a percentage of around $76.30 \%$, followed by IBA and finally IAA. The concentrations studied show that for the same auxin and from $2.5 \mu \mathrm{M}$, the results obtained are often similar and without significant difference. However, it should be noted that the status and color of calli are better only in the presence of NAA (Table 2).

\subsubsection{Effect of different concentrations of BAP}

The association of different concentrations of BAP with the two most appropriate NAA concentrations shows that the most favorable combination, giving a maximum percentage of callogenous explants with large calli, is $5 \mu \mathrm{M}$ NAA and 2.22 $\mu \mathrm{M}$ BAP. However, it should be noted that the results obtained for BAP concentrations between 2.22 and $6.66 \mu \mathrm{M}$ are close and without significant difference in many cases. Moreover, after the third week, when the concentration of NAA is high, there is a slight blackening of the calli, especially when the concentration of BAP exceeds $2.22 \mu \mathrm{M}$ (Table 3). 
Table 1. Effect of three macronutrient solutions on apex callogenesis of young carob seedlings after 30 days of culture in the presence of BAP $(2.22$ and $4.44 \mu \mathrm{M})$ combined with NAA $(5 \mu M)$

\begin{tabular}{lllll}
\hline & $\begin{array}{l}\text { BAP } \\
(\boldsymbol{\mu M})\end{array}$ & $\begin{array}{l}\text { Callogenesi } \\
\mathbf{s}(\%)\end{array}$ & $\begin{array}{l}\text { Callus diameter } \\
(\mathbf{m m})\end{array}$ & Comments \\
\hline WP & 2.22 & $79.45 \mathrm{~b}$ & $13.5 \pm 1.2 \mathrm{~b}$ & $\begin{array}{l}\text { White green callus, compact, friable and well } \\
\text { developed }\end{array}$ \\
M & 4.44 & $88.65 \mathrm{a}$ & $15.7 \pm 1.3 \mathrm{a}$ & Brown callus, compact, hard and undeveloped \\
$\mathrm{SH}$ & 2.22 & $26.22 \mathrm{e}$ & $6.6 \pm 0.7 \mathrm{~d}$ & \\
& 4.44 & $34.34 \mathrm{~d}$ & $7.1 \pm 0.6 \mathrm{~d}$ & White green callus, sometimes brown, compact, \\
$\mathrm{MS}$ & 2.22 & $44.44 \mathrm{c}$ & $11.5 \pm 0.9 \mathrm{c}$ & friable and often well developed \\
\multicolumn{4}{c}{ Results are compared by ANOVA using Duncan's Multiple Range test $(P=.05)$, values with the same letters on the } \\
same column do not show a significant difference
\end{tabular}

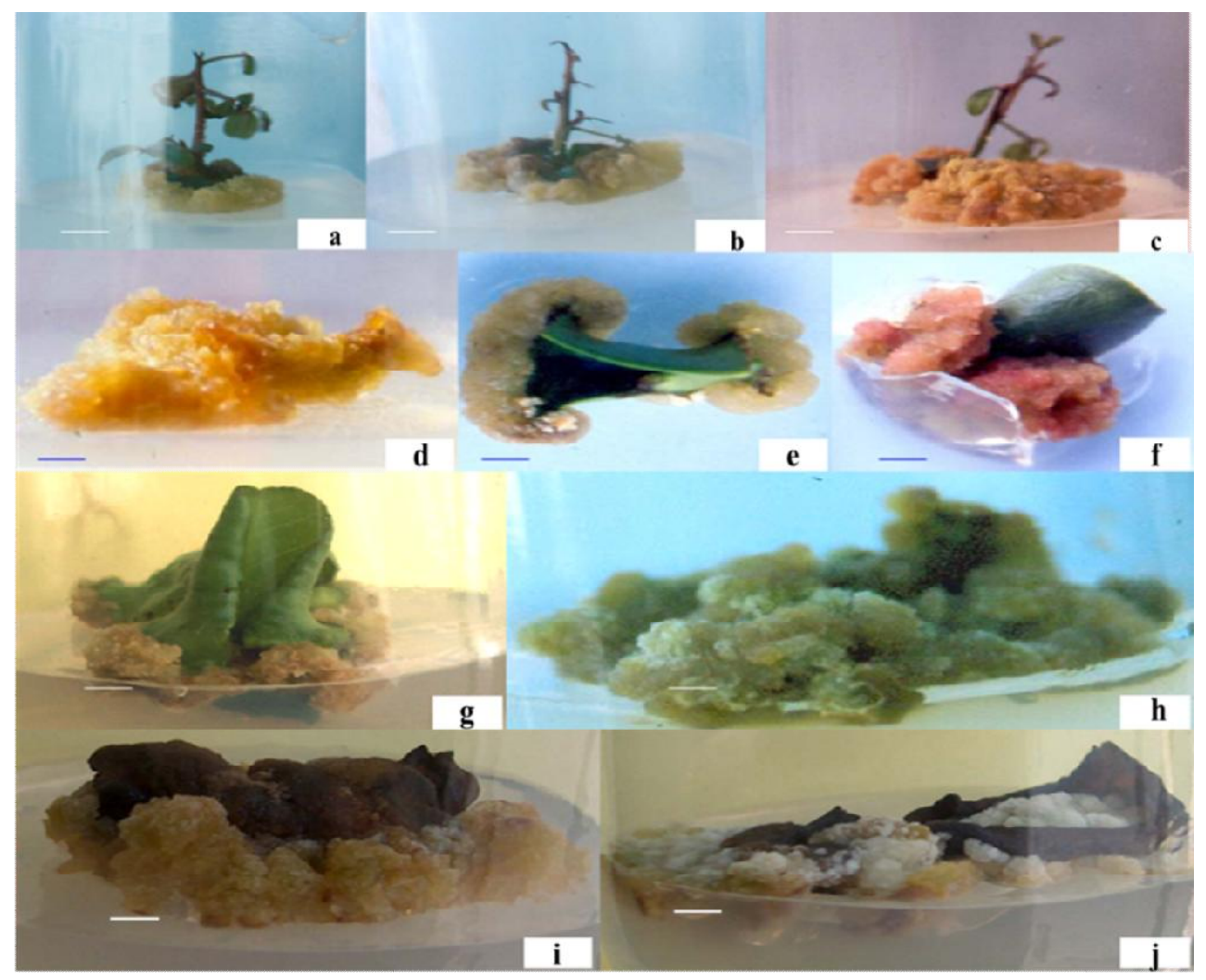

Fig. 1. Induction of calli from different types of explants

(a) Callus obtained after culture of apex on WPM medium supplemented with BAP (2.22 $\mu M)$ associated with NAA (5 $\mu M)$ during one month; (b) Callus obtained after apex culture on WPM medium supplemented with BAP (4.44 $\mu \mathrm{M})$ associated with NAA (5 $\mu \mathrm{M})$ during one month; (c) Callus obtained after culture of apex on MS medium supplemented with BAP (4.44 $\mu \mathrm{M})$ associated with NAA (5 $\mu \mathrm{M})$ during one month; (d) Callus obtained after culture of hypocotyl on WPM medium supplemented with BAP (4.44 $\mu \mathrm{M})$ associated with NAA (5 $\mu M)$ during one month; (e) Callus obtained after culture of cotyledonary leaves on WPM medium supplemented with BAP (2.22 $\mu M)$ associated with NAA (5 $\mu M)$ during one month; (f) Callus obtained after culture of cotyledonary leaves on WPM medium supplemented with BAP $(4.44 \mu \mathrm{M})$ associated with NAA (5 $\mu \mathrm{M})$ during one month; $(g)$ Callus obtained after culturing elite female leaf on WPM medium supplemented with BAP (4.44 $\mu \mathrm{M})$ associated with

NAA (5 $\mu \mathrm{M})$ during one month; (h) Callus obtained after culturing mature female leaf on MS medium supplemented with BAP (4.44 $\mu \mathrm{M})$ associated with NAA (5 $\mu \mathrm{M})$ during one month; (i) Callus obtained after culturing mature female leaf on WPM medium supplemented with BAP $(4.44 \mu \mathrm{M})$ associated with 2, 4-D (5 $\mu M)$ during one month; (j) Callus obtained after culturing mature female leaf on WPM medium supplemented with BAP $(4.44 \mu \mathrm{M})$ associated with IAA (5 $\mu \mathrm{M})$ during one month 
Table 2. Effect of different auxins on the apex callogenesis of young carob seedlings after 30 days of culture on WPM medium in the presence of BAP $(4.44 \mu \mathrm{M})$

\begin{tabular}{|c|c|c|c|c|}
\hline \multicolumn{2}{|c|}{ Auxins $(\mu \mathrm{M})$} & \multirow{2}{*}{$\begin{array}{l}\begin{array}{l}\text { Callogenesis } \\
\text { (\%) }\end{array} \\
35.18 \mathrm{~h}\end{array}$} & \multirow{2}{*}{$\begin{array}{l}\begin{array}{l}\text { Callus diameter } \\
(\mathrm{mm})\end{array} \\
2.2 \pm 0.1 \mathrm{~h}\end{array}$} & \multirow{2}{*}{$\begin{array}{l}\text { Comments } \\
\text { Calli white, hard and compact }\end{array}$} \\
\hline Blank & 0 & & & \\
\hline \multirow[t]{4}{*}{ IAA } & 0.5 & $47.12 \mathrm{~g}$ & $3.1 \pm 0.1 \mathrm{~g}$ & \multirow{4}{*}{$\begin{array}{l}\text { Calli generally white compact and friable, } \\
\text { sometimes slightly blackened, especially when } \\
\text { the concentration of IAA exceeds } 5 \mu \mathrm{M}\end{array}$} \\
\hline & 2.5 & $56.75 f$ & $4.7 \pm 0.3$ ef & \\
\hline & 5 & $62.25 f$ & $5.6 \pm 0.4 d$ & \\
\hline & 7.5 & $59.20 f$ & $5.8 \pm 0.4 d$ & \\
\hline \multirow[t]{4}{*}{ IBA } & 0.5 & $49.23 \mathrm{~g}$ & $4.5 \pm 0.3 \mathrm{ef}$ & \multirow{4}{*}{$\begin{array}{l}\text { Calli white yellow, compact and often hard, with } \\
\text { fragments difficult to collect during their } \\
\text { transplanting }\end{array}$} \\
\hline & 2.5 & $68.48 \mathrm{e}$ & $6.0 \pm 0.5 d$ & \\
\hline & 5 & 70.14de & $7.2 \pm 0.6 c$ & \\
\hline & 7.5 & $71.50 \mathrm{cde}$ & $7.5 \pm 0.6 c$ & \\
\hline \multirow[t]{4}{*}{ NAA } & 0.5 & $60.00 f$ & $5.2 \pm 0.5 d$ & \multirow{4}{*}{$\begin{array}{l}\text { Calli green, compact and friable, easy to } \\
\text { handle, that can even be used for cell culture } \\
\text { after transplanting }\end{array}$} \\
\hline & 2.5 & $88.67 a$ & $13.5 \pm 1.1 a$ & \\
\hline & 5 & $90.33 a$ & $14.1 \pm 1.3 a$ & \\
\hline & 7.5 & $82.52 b$ & $13.4 \pm 1.2 a$ & \\
\hline \multirow[t]{4}{*}{$2,4-D$} & 0.5 & $61.14 f$ & $4.0 \pm 0.2 f$ & \multirow{4}{*}{$\begin{array}{l}\text { Calli white yellow, with a slight blackening } \\
\text { appearing at the end of the third week which } \\
\text { bothers their maintenance after transplanting }\end{array}$} \\
\hline & 2.5 & $69.56 e$ & $7.8 \pm 0.6 c$ & \\
\hline & 5 & $75.29 \mathrm{~cd}$ & $9.4 \pm 1.0 b$ & \\
\hline & 7.5 & $76.30 c$ & $9.5 \pm 0.8 b$ & \\
\hline
\end{tabular}

Table 3. Effect of different concentrations of BAP associated with NAA ( 5 and $7.5 \mu \mathrm{M})$ on the apex callogenesis from young carob seedlings after 30 days of culture on WPM

\begin{tabular}{|c|c|c|c|c|}
\hline $\begin{array}{l}\text { NAA } \\
(\mu M)\end{array}$ & $\begin{array}{l}\text { BAP } \\
(\mu \mathrm{M})\end{array}$ & $\begin{array}{l}\text { Callogenesis } \\
(\%)\end{array}$ & $\begin{array}{l}\text { Callus diameter } \\
\text { (mm) }\end{array}$ & Comments \\
\hline \multirow[t]{6}{*}{5} & 0 & $15.65 \mathrm{~g}$ & $2.5 \pm 0.1 \mathrm{~g}$ & \multirow{6}{*}{$\begin{array}{l}\text { Calli in a good state, with yellow-green color, } \\
\text { compact and easily friable, forming a crown } \\
\text { around the explants; their important } \\
\text { development with high BAP concentration } \\
\text { bothers caulogenesis }\end{array}$} \\
\hline & 0.44 & $30.43 f$ & $3.1 \pm 0.2 \mathrm{~g}$ & \\
\hline & 1.33 & $42.50 \mathrm{e}$ & $5.3 \pm 0.4 f$ & \\
\hline & 2.22 & $89.82 a$ & $14.0 \pm 1.3 a$ & \\
\hline & 4.44 & $88.15 a$ & $13.6 \pm 1.2 b$ & \\
\hline & 6.66 & $84.00 a b$ & $13.5 \pm 1.2 b$ & \\
\hline \multirow[t]{6}{*}{7.5} & 0 & $39.42 e$ & $3.4 \pm 0.2 \mathrm{~g}$ & \multirow{6}{*}{$\begin{array}{l}\text { Calli yellow white, compact and friable, a } \\
\text { slight blackening occurring after the third } \\
\text { week, especially for concentrations of BAP } \\
\text { beyond } 2.22 \mu \mathrm{M}\end{array}$} \\
\hline & 0.44 & $63.63 d$ & $4.8 \pm 0.3 f$ & \\
\hline & 1.33 & $74.82 c$ & $6.5 \pm 0.5 \mathrm{e}$ & \\
\hline & 2.22 & $80.57 \mathrm{bc}$ & $12.4 \pm 1.1 \mathrm{c}$ & \\
\hline & 4.44 & $83.20 \mathrm{ab}$ & $12.7 \pm 1.1 \mathrm{~cd}$ & \\
\hline & 6.66 & $84.98 \mathrm{ab}$ & $11.2 \pm 1.2 d$ & \\
\hline
\end{tabular}

Table 4. Callogenesis of different types of carob explants on WPM medium, in the presence of BAP and NAA $(5 \mu \mathrm{M})$ after 30 days

\begin{tabular}{|c|c|c|c|c|}
\hline $\begin{array}{l}\text { Type of } \\
\text { explants }\end{array}$ & $\begin{array}{l}\text { BAP } \\
(\mu \mathrm{M})\end{array}$ & $\begin{array}{l}\text { Callogenesis } \\
(\%)\end{array}$ & $\begin{array}{l}\text { Callus diameter } \\
(\mathrm{mm})\end{array}$ & Comments \\
\hline Cotyledonary & 2.22 & $60.35 b$ & $11.2 \pm 1.0 a$ & Green, compact and friable yellow \\
\hline leaves & 4.44 & $62.49 \mathrm{~b}$ & $10.8 \pm 0.9 a$ & calli, easy to transplant \\
\hline \multirow[t]{2}{*}{ Hypocotyls } & 2.22 & $54.54 c$ & $5.0 \pm 0.3 d$ & Transformation of the whole explant \\
\hline & 4.44 & $20.70 d$ & $3.6 \pm 0.2 \mathrm{e}$ & into a yellow green callus \\
\hline Embryonic & 2.22 & $81.46 a$ & $8.3 \pm 0.6 b$ & Yellow green calli, sometimes \\
\hline cotyledons & 4.44 & $85.00 \mathrm{a}$ & $7.1 \pm 0.8 c$ & $\begin{array}{l}\text { accompanied by the development of } \\
\text { adventitious buds }\end{array}$ \\
\hline
\end{tabular}




\subsection{Callogenesis from Other Explants of Young Seedlings Grown In vitro}

For carob, callogenesis can be induced from various explants. In most cases, callus development occurs along the organ in contact with the culture medium. The best percentage of callogenesis is obtained during the culture of embryonic cotyledons, with similar values for the two concentrations studied. However, calli size is larger in the case of cotyledonary leaves (Table 4, Fig. 1d, 1e, 1f).

\subsection{Callogenesis from the Leaves of an Elite Tree}

\subsubsection{Effect of macronutrient solutions}

The percentage of callogenesis as well as the diameter of the calli are greater on WPM medium and are respectively $84.00 \%$ and $10.6 \mathrm{~mm}$ for $4.44 \mu \mathrm{M}$ of BAP; in this case, calli are generally in good condition and easy to transplant. The MS macronutrient solution is less efficient (Table 5, Fig. 1g, 1h).

\subsubsection{Effect of different auxins}

The study of the impact of different auxins (IAA, IBA, BNOA, AIP, NAA and 2,4-D) associated with BAP (2.22 and $4.44 \mu \mathrm{M})$ on callogenesis from leaves of an elite tree, showed that NAA is the most effective for the induction of calli and their development, whatever the concentration of BAP. Percentages of callogenesis (78 and $84 \%$ ) and callus diameter (10.5 and $10.7 \mathrm{~mm}$ ) form the same statistical class. 2,4-D is in second place with good results close to those obtained with NAA, while other auxins are less effective, especially AIP and BNOA (Table 6, Fig. 1i, 1j).

\subsection{Calli Growth after Transplanting}

\subsubsection{Effect of different auxins on calli growth}

The transplanting of the calli under different conditions is accompanied by very considerable growth. In most cases, their size exceeds $20 \mathrm{~mm}$ after 21 days. Maximum values of size, weight of fresh and dry matter are obtained in the presence of NAA, in particular at $5 \mu \mathrm{M}(28.1 \mathrm{~mm}$, 4.13 and $0.40 \mathrm{~g}$, respectively). The results obtained with the IBA come in the second place, but this time with $2.5 \mu \mathrm{M}$. Generally, IAA and 2,4-
D give results with no significant difference (Table 7, Fig. 2a to 2d).

\subsubsection{Effect of NAA combined with BAP on calli growth}

According to Table 8 and Fig. 3 and 4, it can be seen that during the first days, calli are less reactive, but as early as the second week, they are organized and the cell multiplication intensifies. Often, clubs are formed which eventually come together. The growth of calli is the most important between the fifth and fifteenth days. It results in a steep slope which tends to dampen on the twentieth day. Beyond this time, there is a marked slowdown in growth and a plateau is achieved. After the third week, calli begin to blacken. From the 45th day, their transplanting becomes very difficult. Measurement of the size and weight of fresh material are good parameters for visualizing the most active period (Fig. $2 \mathrm{e}$ to $2 \mathrm{~h}$ ).

\section{DISCUSSION}

For carob tree, callogenesis induction from various explants presents no problem. WPM medium is the most favorable among the three culture media studied for the initiation of calli. These results concur with those obtained in cork oak by El Kbiach et al. [39]. The low efficiency of $\mathrm{SH}$ and MS media could be attributed to their nitrogen richness, in particular ammonia nitrogen, which reduces the rate of cell proliferation [40,41]. Thus, WPM medium constitutes a medium of choice for the in vitro culture of carob tree.

The study of the effect of different auxins combined with BAP on callogenesis from apex shows that NAA is the most suitable for the development of calli, their growth and their maintenance. They are usually green yellow (chlorophylls) and easy to handle. Among the various other explants (cotyledonary leaves, embryonic cotyledons and hypocotyls), embryonic cotyledons also show a high callogenous capacity, but it remains slightly lower than that of the apexes.

The efficiency of NAA on callogenesis was proven by various researchers for other woody plants such as Quercus rubra $[42,43]$, Q. robur [44] or Q. suber [39]. For carob, NAA was successfully used for callogenesis from hypocotyls $(75 \%)$ and cotyledons $(57.1 \%)$ with 1 $\mathrm{mg} / \mathrm{l} \mathrm{NAA}$ and $2 \mathrm{mg} / \mathrm{l} \mathrm{BAP}$ [12], apex of young seedlings $(66-80 \%)$ in the presence of $1 \mathrm{mg} / \mathrm{l}$ 
BAP associated with $0.1 \mathrm{mg} / \mathrm{l} \mathrm{NAA} \mathrm{[15],} \mathrm{also} \mathrm{with}$ nodal segments of young seedlings in a media containing $1 \mathrm{mg} / \mathrm{l}$ BAP in combination with $1 \mathrm{mg} / \mathrm{l}$ NAA [19]. However, for other studies on carob, the best results for callus induction were obtained with 2,4-D in the case of roots $(28.6 \%)$ [12], anthers (100\%) [29], immature seeds (67\%) [30], portions of hypocotyls $(58.3 \%)$ and cotyledons (100\%) [18] and mature cotyledons of seed $(100 \%)$ [31].

Table 5. Effect of two solutions of macronutrients (WPM and MS), supplemented with BAP (2.22 and 4.44 $\mu \mathrm{M})$, on the callogenesis of the foliar leaf blades from an elite female carob tree, after 30 days of culture

\begin{tabular}{|c|c|c|c|c|}
\hline Macronutrients & BAP $(\mu M)$ & Callogenesis (\%) & Callus diameter (mm) & Comments \\
\hline \multirow[t]{2}{*}{ WPM } & 2.22 & $78 a$ & $10.5 \pm 0.8 a$ & \multirow{2}{*}{$\begin{array}{l}\text { Yellow and friable calli, } \\
\text { generally well developed }\end{array}$} \\
\hline & 4.44 & $84 a$ & $10.6 \pm 0.9 a$ & \\
\hline \multirow[t]{2}{*}{ MS } & 2.22 & $40 b$ & $8.1 \pm 0.7 b$ & \multirow{2}{*}{$\begin{array}{l}\text { Friable and often well- } \\
\text { developed yellow calli }\end{array}$} \\
\hline & 4.44 & $84 a$ & $8.8 \pm 0.7 b$ & \\
\hline
\end{tabular}

Table 6. Effect of different auxins $(2.26 \mu \mathrm{M})$ combined with BAP $(2.22$ and $4.44 \mu \mathrm{M})$ on the callogenesis of leaf blades from an elite female carob tree, on the WPM medium for $\mathbf{3 0}$ days

\begin{tabular}{|c|c|c|c|c|}
\hline $\begin{array}{l}\text { Auxins } \\
(2.26 \mu \mathrm{M})\end{array}$ & $\begin{array}{l}\text { BAP } \\
(\mu \mathrm{M})\end{array}$ & $\begin{array}{l}\text { Callogenesis } \\
(\%)\end{array}$ & $\begin{array}{l}\text { Callus } \\
\text { diameter }(\mathrm{mm})\end{array}$ & Comments \\
\hline \multirow[t]{2}{*}{0} & 2.22 & $21 \mathrm{e}$ & $3.2 \pm 0.3 e$ & Yellow white calli, sometimes hard and compact \\
\hline & 4.44 & $28 \mathrm{e}$ & $4.8 \pm 0.5 d$ & \\
\hline \multirow[t]{2}{*}{ IAA } & 2.22 & $40 d$ & $6.3 \pm 0.6 c$ & Yellow, friable and moderately developed calli \\
\hline & 4.44 & $40 d$ & $7.8 \pm 0.7 b$ & \\
\hline \multirow[t]{2}{*}{ IBA } & 2.22 & $7 f$ & $3.5 \pm 0.3 e$ & Yellow, friable and very undeveloped calli \\
\hline & 4.44 & $27 e$ & $3.8 \pm 0.4 \mathrm{e}$ & \\
\hline \multirow[t]{2}{*}{ BNOA } & 2.22 & $20 e$ & $4.5 \pm 0.5 d$ & Yellow, friable and undeveloped calli \\
\hline & 4.44 & $7 f$ & $3.0 \pm 0.3 e$ & \\
\hline \multirow[t]{2}{*}{ AIP } & 2.22 & $7 f$ & $2.9 \pm 0.05 e$ & Yellow, friable and undeveloped calli \\
\hline & 4.44 & $20 e$ & $4.9 \pm 0.5 d$ & \\
\hline \multirow[t]{2}{*}{ NAA } & 2.22 & $78 a$ & $10.5 \pm 0.6 a$ & Friable and well-developed yellow calli \\
\hline & 4.44 & $84 a$ & $10.7 \pm 0.7 a$ & \\
\hline \multirow[t]{2}{*}{$2,4-D$} & 2.22 & $67 \mathrm{~b}$ & $10.5 \pm 0.9 a$ & Yellow brown, friable and well-developed calli \\
\hline & 4.44 & $53 c$ & $10.4 \pm 0.8 a$ & \\
\hline
\end{tabular}

Results are compared by ANOVA using Duncan's Multiple Range test $(P=.05)$, values with the same letters on the same column do not show a significant difference

Table 7. Effect of different auxins associated with BAP $(2.22 \mu \mathrm{M})$ on callus growth after transplanting on WPM medium for 21 days

\begin{tabular}{|c|c|c|c|c|c|}
\hline Auxin & $\mu \mathrm{M})$ & $\begin{array}{l}\text { Callus } \\
\text { diameter } \\
(\mathrm{mm})\end{array}$ & FW (g) & DW (g) & Comments \\
\hline IAA & $\begin{array}{l}2.5 \\
5\end{array}$ & $\begin{array}{l}23.3 \pm 1.7 b \\
22.2 \pm 1.5 c\end{array}$ & $\begin{array}{l}3.57 \pm 0.2 c \\
2.31 \pm 0.2 e\end{array}$ & $\begin{array}{l}0.28 \pm 0.06 \mathrm{~cd} \\
0.25 \pm 0.07 \mathrm{de}\end{array}$ & $\begin{array}{l}\text { Compact friable calli, of yellow white } \\
\text { color, with an early darkening at high } \\
\text { concentration }\end{array}$ \\
\hline IBA & $\begin{array}{l}2.5 \\
5\end{array}$ & $\begin{array}{l}25.4 \pm 1.8 b \\
17.1 \pm 1.4 d\end{array}$ & $\begin{array}{l}4.18 \pm 0.3 b \\
2.06 \pm 0.2 e\end{array}$ & $\begin{array}{l}0.34 \pm 0.08 b \\
0.22 \pm 0.05 e\end{array}$ & $\begin{array}{l}\text { Same observation as that of calli } \\
\text { cultured in the presence of IAA, only } \\
\text { the size differs }\end{array}$ \\
\hline NAA & $\begin{array}{l}2.5 \\
5\end{array}$ & $\begin{array}{l}28.1 \pm 2.2 a \\
25.7 \pm 2.1 b\end{array}$ & $\begin{array}{l}4.13 \pm 0.3 b \\
4.73 \pm 0.3 a\end{array}$ & $\begin{array}{l}0.40 \pm 0.09 a \\
0.40 \pm 0.1 a\end{array}$ & $\begin{array}{l}\text { Yellow calli, in good condition and } \\
\text { sometimes showing flavonoids, with a } \\
\text { slight blackening at high concentration }\end{array}$ \\
\hline $2,4-D$ & $\begin{array}{l}2.5 \\
5\end{array}$ & $\begin{array}{l}23.4 \pm 2.0 b \\
21.6 \pm 1.6 c\end{array}$ & $\begin{array}{l}3.25 \pm 0.2 \mathrm{~cd} \\
3.10 \pm 0.2 \mathrm{~d}\end{array}$ & $\begin{array}{l}0.31 \pm 0.07 b c \\
0.28 \pm 0.06 c d\end{array}$ & $\begin{array}{l}\text { White yellow, compact and friable } \\
\text { calli, often in good condition, with } \\
\text { blackening in high concentration }\end{array}$ \\
\hline
\end{tabular}


Table 8. Time-dependent growth of calli transplanted on WPM medium, with BAP $(2.22 \mu \mathrm{M})$ and NAA $(2.5 \mu \mathrm{M})$

\begin{tabular}{llll}
\hline Time (Days) & Callus diameter $(\mathbf{m m})$ & FW $(\mathbf{g})$ & DW $(\mathbf{g})$ \\
\hline 0 & $6.1 \pm 0.5 \mathrm{f}$ & $0.89 \pm 0.1 \mathrm{c}$ & $0.08 \pm 0.01 \mathrm{~g}$ \\
5 & $7.3 \pm 0.4 \mathrm{f}$ & $1.15 \pm 0.1 \mathrm{c}$ & $0.11 \pm 0.01 \mathrm{~g}$ \\
10 & $13.7 \pm 0.6 \mathrm{e}$ & $2.05 \pm 0.2 \mathrm{~b}$ & $0.20 \pm 0.02 \mathrm{f}$ \\
15 & $23.5 \pm 2.1 \mathrm{~d}$ & $3.41 \pm 0.3 \mathrm{~b}$ & $0.33 \pm 0.03 \mathrm{e}$ \\
20 & $27.3 \pm 2.5 \mathrm{c}$ & $3.89 \pm 0.3 \mathrm{ab}$ & $0.38 \pm 0.04 \mathrm{~d}$ \\
25 & $29.2 \pm 1.7 \mathrm{~b}$ & $4.08 \pm 0.5 \mathrm{ab}$ & $0.39 \pm 0.03 \mathrm{~cd}$ \\
30 & $30.4 \pm 1.1 \mathrm{ab}$ & $4.25 \pm 0.3 \mathrm{a}$ & $0.41 \pm 0.02 \mathrm{bcd}$ \\
35 & $31.6 \pm 0.6 \mathrm{a}$ & $4.38 \pm 0.2 \mathrm{a}$ & $0.43 \pm 0.02 \mathrm{abc}$ \\
40 & $31.8 \pm 0.5 \mathrm{a}$ & $4.45 \pm 0.1 \mathrm{a}$ & $0.45 \pm 0.01 \mathrm{ab}$ \\
45 & $31.9 \pm 0.2 \mathrm{a}$ & $4.47 \pm 0.05 \mathrm{a}$ & $0.46 \pm 0.01 \mathrm{a}$ \\
\hline
\end{tabular}

Results are compared by ANOVA using Duncan's Multiple Range test $(P=.05)$, values with the same letters on the same column do not show a significant difference

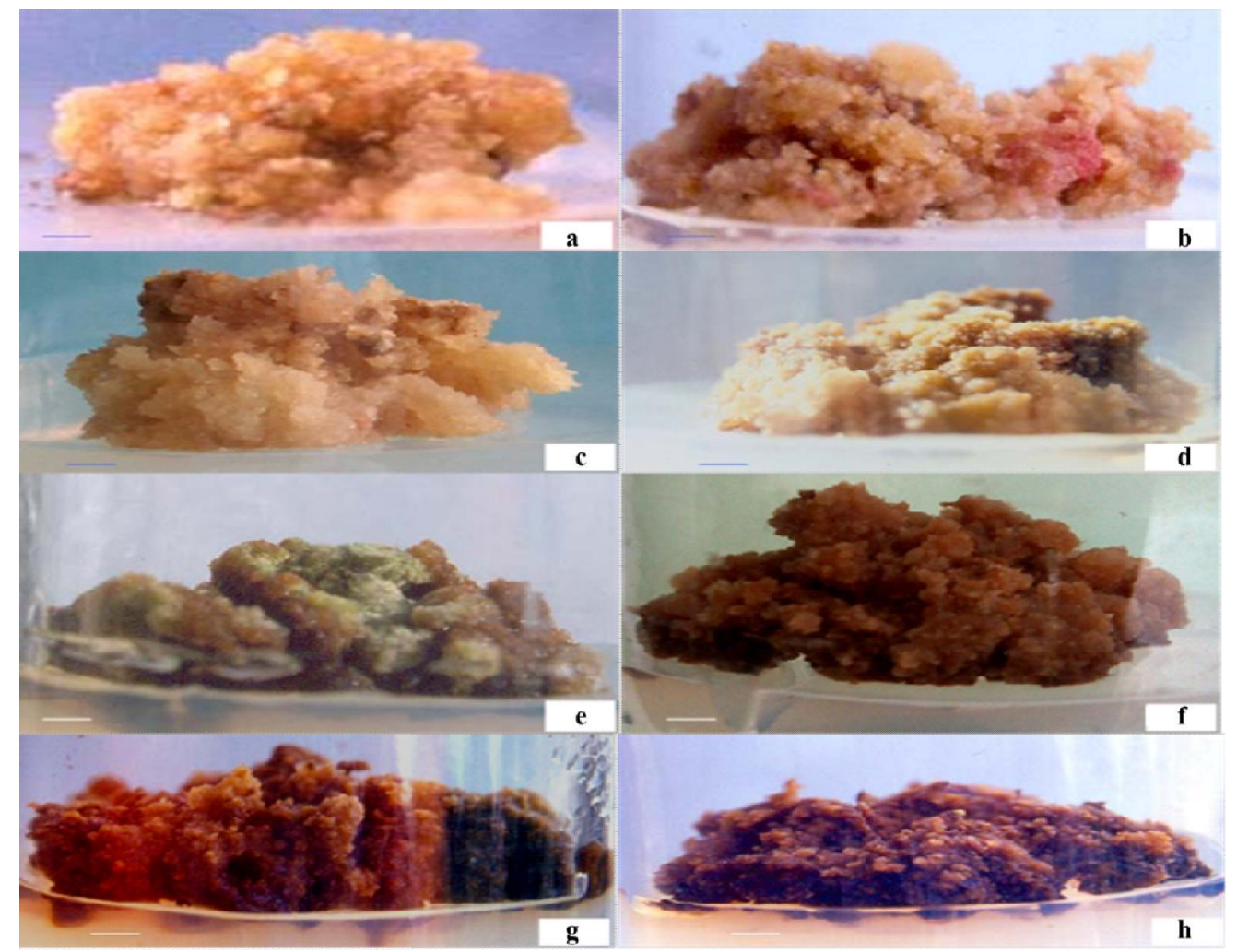

Fig. 2. Multiplication and growth of calli

(a) Callus obtained from apex after 7 successive subcultures on WPM medium supplemented with BAP (2.22 $\mu \mathrm{M})$ associated to NAA (2.5 $\mu \mathrm{M})$ during 21 days; (b) Callus obtained from apex after 7 successive subcultures on WPM medium supplemented with BAP (2.22 $\mu \mathrm{M})$ associated to NAA (2.5 $\mu \mathrm{M})$ during 30 days; (c) Callus obtained from apex after 7 successive subcultures on WPM medium supplemented with BAP (2.22 $\mu M)$ associated to 2,4-

$D(2.5 \mu M)$ during 21 days; (d) Callus obtained from apex after 7 successive subcultures on WPM medium supplemented with BAP (2.22 $\mu \mathrm{M})$ associated to 2,4-D (2.5 $\mu \mathrm{M})$ during 30 days; (e) Callus obtained from apex after 7 successive subcultures on WPM medium supplemented with BAP (2.22 $\mu$ M) associated to NAA (2.5 $\mu$ M) during 45 days; (f) Callus obtained from apex after 7 successive subcultures on WPM medium supplemented with $B A P(2.22 \mu \mathrm{M})$ associated to 2,4-D $(2.5 \mu \mathrm{M})$ during 45 days; $(g)$ Callus obtained from apex after 7 successive subcultures on WPM medium supplemented with BAP (2.22 $\mu M)$ associated with to NAA (2.5 $\mu M)$ during 60 days; (h) Callus obtained from apex after 7 successive subcultures on WPM medium supplemented with $B A P(2.22 \mu \mathrm{M})$ associated to 2,4-D (2.5 $\mu \mathrm{M})$ during 60 days 


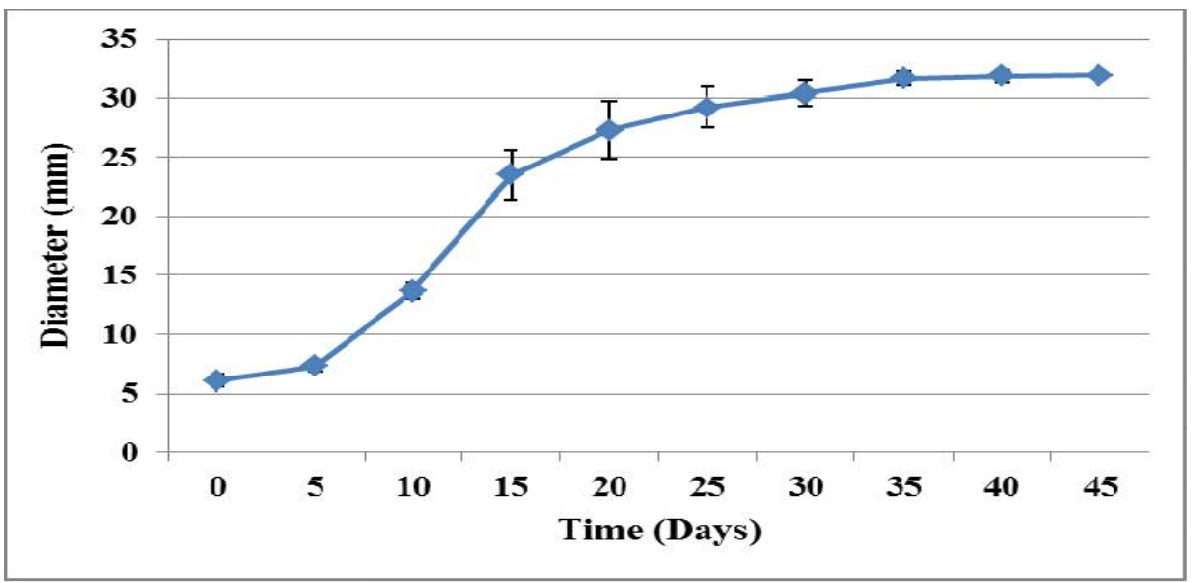

Fig. 3. Variation of the size of calli after transplanting on WPM medium, supplemented with BAP $(2.22 \mu \mathrm{M})$ and NAA $(2.5 \mu \mathrm{M})$

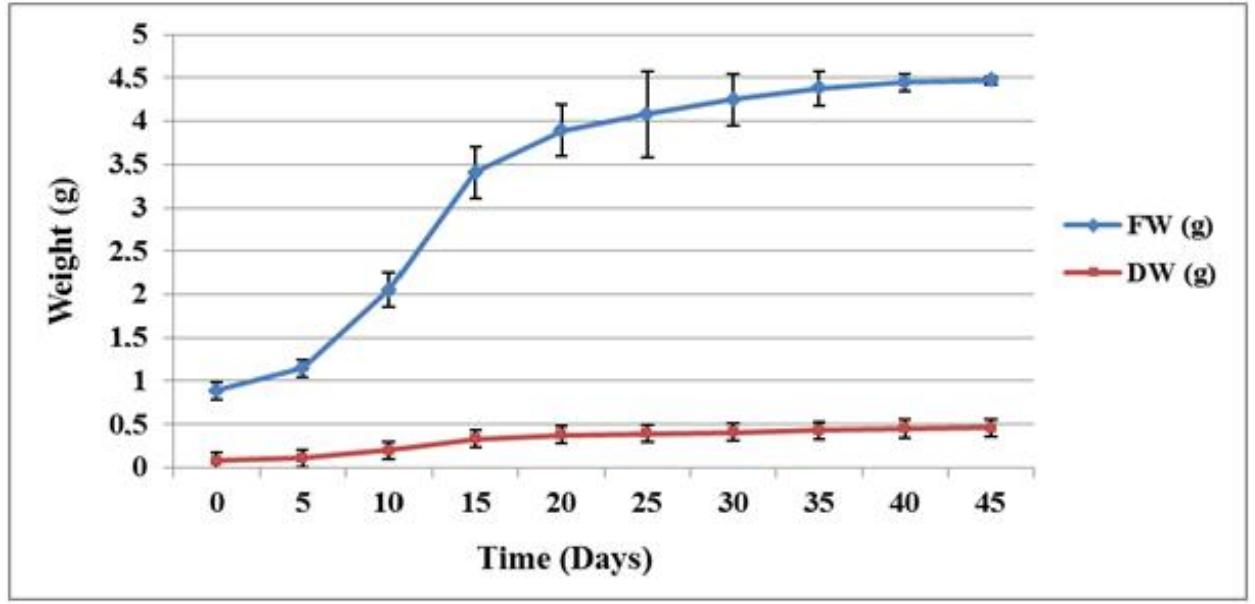

Fig. 4. Variation of callus weight after transplanting onto WPM medium, supplemented with BAP $(2.22 \mu \mathrm{M})$ and NAA $(2.5 \mu \mathrm{M})$

Among the concentrations of BAP combined with NAA, it was found that concentrations 2.22 and $4.44 \mu \mathrm{M}$ give most often similar results without significant difference, in particular when the concentration of NAA is equivalent to $5 \mu \mathrm{M}$. The combination of $2.22 \mu \mathrm{M}$ of BAP and $5 \mu \mathrm{M}$ of NAA could therefore be a prerequisite for further studies. For Belaizi et al. [14], BAP concentrations higher than $0.5 \mathrm{mg} / \mathrm{l}$ result in high callogenesis. Carimi et al. [28] obtained good calli $(16 \%)$ from ovules derived from young carob pods with $13.3 \mu \mathrm{M}$ BAP, but they worked on MS medium supplemented with malt extract.

The leaves of the mature tree have a considerable callogenous capacity, in particular on the WPM medium supplemented with BAP $(4.44 \mu \mathrm{M})$ and NAA $(1.26 \mu \mathrm{M})$. The association of BAP with other auxins is generally less efficient, but 2,4-D has also considerable callogenous capacity. These results are in concordance with those obtained in the study of callogenesis from apex of young seedlings. The callogenous capacity of explants from mature trees was also observed by other researchers [4,13,23-27].

The transplanting of calli obtained from different types of explants makes it possible to stabilize their proliferation. Overall, the conditions that favor this proliferation are those considered favorable for their initiation. The study of the effect of different combinations of BAP with auxins also showed that NAA is the most suitable auxin for proliferation of callus. The dry weights are similar for the two combinations studied (BAP at $2.22 \mu \mathrm{M}$ and NAA at 2.5 or $5 \mu \mathrm{M}$ ). During the proliferation phase, we did not observe primary 
somatic embryogenesis. Contrariwise, Custodio et al. [29], Ksia et al. [30] and Lozzi et al. [31] induced primary somatic embryogenesis from the obtained calli.

It should be noted that, after several successive subcultures, very friable calli clusters are obtained which can well serve to obtain cell suspensions. Tests in this direction are under study.

The proliferation of calli and their maintenance is blocked by the problem of blackening, which is accentuated by their age. From the third week, the calli begin to change color. After 40 to 45 days, they become hard and compact and their transplanting then becomes impossible. The blackening of calli may be attributed to an accumulation of polyphenols. Research on these polyphenols and their degree of accumulation depending on culture conditions would be useful.

\section{CONCLUSION}

The study of calli induction by using varied explants made it possible to optimize the conditions of callogenesis as well as those of their maintenance and their multiplication. WPM medium supplemented with BAP $(2.22 \mu \mathrm{M})$ associated to NAA $(5 \mu \mathrm{M})$ is the most favorable condition. Percentage callus formation in apex seedlings (89\%) and embryonic cotyledons of seed $(81 \%)$ was greater than in leaves of mature tree $(78 \%)$, cotyledonary leaves $(60 \%)$ and hypocotyls $(54 \%)$ seedlings. Optimization of callogenesis can be exploited to initiate the culture of cell suspensions and to initiate somatic embryogenesis.

\section{COMPETING INTERESTS}

Authors have declared that no competing interests exist.

\section{REFERENCES}

1. Batlle I, Tous J. Carob tree. Ceratonia siliqua L. International Plant Genetic Resources Institute, Rome. 1997;92.

2. Sidina MM, El Hansali $M$, Wahid $N$, Ouatmane A, Boulli A, Haddioui A. Fruit and seed diversity of domesticated carob (Ceratonia siliqua L.) in Morocco. Scientia Horticulturae. 2009;123(1):110-116.

3. Mitrakos K. The botany of Ceratonia. Proceedings of the $2^{\text {nd }}$ International Carob
Symposium, Valencia, 29 September-1 October. 1987;209-218.

4. Romano A, Barros S, Martins-Louçao MA. Micropropagation of the mediterranean tree Ceratonia siliqua L. Plant Cell, Tissue and Organ Culture. 2002;68:35-41.

5. Durzan DJ, Steward FC. Cell and tissue culture of white spruce and jack pine. Canadian Department of Forestry and Rural Development Research Report. 1968;24:30-30.

6. Durzan DJ, Steward FC. Morphogenesis in cell cultures of gymnosperms: Some growth patterns. International Union of Forest Research Organizations Section 22, Varparanta, Finland. Abstr. Communicationes Instituti Forestalis Fenniae. 1971;74(6):16-17.

7. Durzan DJ, Chalupa V, Mia AJ. Growth and metabolism of cells and tissues of jack pine (Pinus banksiana). Canadian Journal of Botany. 1976 ;54(5-6):437-445.

8. Bigot $C$. Comparaison des aptitudes pour le bourgeonnement de tissus superficiels et de tissus profonds cultivés in vitro. Cas de la tige d'Atropa Belladonna L.. Comptes Rendus de l'Académie des Sciences. 1974;Série D,279:743-746. French.

9. Bigot C. Multiplication végétative de Gloxinia hybrida à partir d'organes cultivés in vitro. Annales de l'Amélioration des Plantes. 1975;25:337-351. French.

10. Ohki S, Bigot C, Mousseau J. Analysis of shoot-forming capacity in vitro in two lines of tomato (Lycopersicon esculentum Mill.) and their hybrids. Plant and Cell Physiology. 1978;19(1):27-42.

11. Jarret RL, Hasegawa PM, Erickson HT. Factors affecting shoot initiation from tuber discs of potato (Solanum tuberosum). Physiologia Plantarum. 1980;49(2):177184.

12. Martins-Loução MA, Rodríguez-Barrueco C. Establishment of proliferating callus from roots, cotyledons and hypocotyls of carob (Ceratonia siliqua L.) seedlings. Journal of Plant Physiology. 1981; 103(4):297-303.

13. Sebastian KT, McComb JA. A micropropagation system for carob (Ceratonia siliqua L.). Scientia Horticulturae. 1986;28(1-2):127-131.

14. Belaizi M, Bolen MR, Boxus $P$. Régénération in vitro et acclimatation du caroubier (Ceratonia siliqua L.). In quel avenir pour l'amélioration des plantes ? 
(Dubois, J., Ed.). John Libbey Eurotext, Paris. 1995;227-232. French.

15. Gharnit N, Ennabili A. Essais préliminaires de culture in vitro du caroubier (Ceratonia siliqua L.) originaire du Nord-Ouest du Maroc. Biomatec Echo. 2009;3:18-25. French.

16. Mohamed Al, Elnour EG, Mahfouz SA. Production of multiple shoots from carob tree (Ceratonia siliqua) using tissue culture technique. Acta Horticulturae (ISHS). 2009;812:211-216.

17. Hakim L, Islam MR, Mamun ANK, Ahmed $\mathrm{G}$, Khan R. Clonal propagation of carob (Ceratonia siliqua L., Fabaceae). Bangladesh Journal of Botany. 2010; 39(1):15-19.

18. Saad AIM, Elnour GE. Induction of callus from hypocotyledons and cotyledonary leaves of Ceratonia siliqua. Acta Horticulturae (ISHS). 2010;865:293-296.

19. Radi A, Echchgadda G, Ibijbijen J, Rochd M. In vitro propagation of Moroccan carob (Ceratonia siliqua L.). Journal of Food, Agriculture \& Environment. 2013;11(1): 1103-1107.

20. Radi A, Echchgadda G, Ibijbijen J, Rochd M. Micropropagation du caroubier (Ceratonia siliqua L.) par culture d'apex. Sciencelib Editions Mersenne. 2013;5(131008). French.

21. Shahzad A, Akhtar R, Bukhari NA, Perveen K. High incidence regeneration system in Ceratonia siliqua L. articulated with SEM and biochemical analysis during developmental stages. Trees. 2017;31(4): 1149-1163.

22. Scaramuzzi F, Porcelli-Armenise V, De Gaetano A. Recherches sur le comportement et le rythme annuel de la callogenèse de fragments de tiges de certains arbres. Comptes Rendus de l'Académie des Sciences de Paris. 1971;Série D,272:2544-2547. French.

23. Thomas V, Mehta AR. Effect of phloroglucinol on shoot growth and initiation of roots in carob tree cultures grown in vitro. In Plant Cell Culture in Crop Improvement (Sen, S.K. and Giles, K.L., Eds.). Plenum Press, New York. 1983;451457.

24. Alorda M, Medrano H. Micropropagacion del algarrobo (Ceratonia siliqua L.) a partir de yemas caulinares de planta joven. Actas del II Congreso Nacional de la Sociedad Española de Ciencias. 1986;2831. Spain.
25. Naghmouchi S, Khouja ML, Rejeb MN, Boussaid $M$. Effect of growth regulators and explant origin on in vitro propagation of Ceratonia siliqua L. via cuttings. Biotechnologie, Agronomie, Société et Environnement. 2008;12(3):251-258. French.

26. Naghmouchi S, Khoudja ML, Romero A, Boussaid M. Micropropagation of carob, Ceratonia siliqua L., by apex culture. Acta Botanica Gallica. 2012;159(3):357-361.

27. Hsina T, El Mtili N. Micropropagation of the female tree Ceratonia siliqua. Cahiers UAE. 2012;6-7:7-12.

28. Carimi F, Di Lorenzo R, Crescimanno FG. Callus induction and somatic embryogenesis in carob (Ceratonia siliqua L.) from ovule culture. Scientia Horticulturae. 1997;70(1):73-79.

29. Custódio L, Carneiro MF, Romano A. Microsporogenesis and anther culture in carob tree (Ceratonia siliqua L.). Scientia Horticulturae. 2005;104(1):65-77.

30. Ksia E, Harzallah-Skhiri F, Verdeil JL, Gouta H, Alemanno L, Bouzid S. Somatic embryo production from immature seeds of carob (Ceratonia siliqua L.): Histological evidence. The Journal of Horticultural Science and Biotechnology. 2008;83(4): 401-406.

31. Lozzi A, Abousalim A, Abdelwahd R. Effet du 2,4-D sur l'induction de l'embryogenèse somatique à partir de cotylédons matures de caroubier (Ceratonia siliqua L.). Revue Marocaine des Sciences Agronomiques et Vétérinaires. 2015;3(3):24-29. French.

32. Schröder CA. Some morphological aspects of fruit tissues grown in vitro. Botanical Gazette. 1961;122(3):198-204.

33. Correia PM, Martins-Loução MA. Preliminary studies on Mycorrrhizae of Ceratonia siliqua L, In Mycorrhizas in integrated systems from genes to plant development (Azcon-Aguilar, C. and Barea, J.M., eds.). New York Botanical Gardens Bronx, NY. 1996;86-88.

34. McCown BH, Lloyd G. Woody Plant Medium (WPM) - A mineral nutrient formulation for microculture of woody plant species. HortScience. 1981;16:453-453.

35. Schenk RU, Hildebrandt AC. Medium and techniques for induction and growth of monocotyledonous and dicotyledonous plant cell cultures. Canadian Journal of Botany. 1972;50(1):199-204.

36. Murashige T, Skoog F. A revised medium for rapid growth and bio assays with 
tobacco tissue cultures. Physiologia Plantarum. 1962;15(3):473-497.

37. El Bouzdoudi B, Saïdi R, Nejjar El Ansari $Z$, El Kbiach ML, Martin P, Badoc A, Lamarti A. Micropropagation of carob (Ceratonia siliqua L.) through adventitious buds of immature embryonic cotyledons. American Journal of Plant Sciences. 2017;8(9):2180-2195.

38. Roland JC, Roland F, Bouteau F, El Maarouf Bouteau $\mathrm{H}$. Biologie végétale. 2, Organisation des plantes à fleurs. Sciences Sup. Atlas. Dunod, Paris, 8e ed. 2008. French.

39. El Kbiach ML, El Bouzdoudi B, Saïdi R, Nejjar El Ansari Z, Rahmouni S, Lamarti A. Callogenesis of cork oak (Quercus suber L.) through in vitro culture of nodes and internodes. American Journal of Plant Sciences. 2017;8(8):1801-1819.

40. Flick CE, Evans DA, Sharp WR. Organogenesis. In Handbook of Plant Cell Culture (Evans, D.A., Ammirato, P.V. and Yamada, Y. eds.). Macmillan Publishing
Company. New York. 1983;volume 1 (Techniques for Propagation and Breeding):13-81.

41. Aboel-Nil MM. Tissue culture of douglas-fir and Western North American conifers. In Cell and tissue culture in forestry (Bonga, J.M. and Durzan, D.J., eds.). Martinus Nijhoff Publisher. Dordrecht. 1987;3:80100.

42. Seckinger GR, McCown BH, Struckmeyer $\mathrm{BE}$, Durbin RD. Production and rapid multiplication of organoids from callus cultures of Quercus rubra L. (Red Oak). HortScience. 1978;13(3):355-355.

43. Seckinger GR, McCown BH, Struckmeyer BE. Production of anomalous structures in Quercus rubra L. callus cultures. American Journal of Botany. 1979;66(8): 993-996.

44. Cuenca B, San-José MC, Martínez MT, Ballester A, Vieitez AM. Somatic embryogenesis from stem and leaf explants of Quercus robur L.. Plant Cell Reports. 1999;18(7-8):538-543.

(c) 2017 El Bouzdoudi et al.; This is an Open Access article distributed under the terms of the Creative Commons Attribution License (http://creativecommons.org/licenses/by/4.0), which permits unrestricted use, distribution, and reproduction in any medium, provided the original work is properly cited.

Peer-review history:

The peer review history for this paper can be accessed here: http://sciencedomain.org/review-history/21733 